\title{
ADRENOMEDULLIN AND PROADRENOMEDULLIN N-TERMINAL 20 PEPTIDE INHIBIT AGONIST-STIMULATED ALDOSTERONE SECRETION OF HUMAN ADRENOCORTICAL CELLS, THROUGH A MECHANISM PROBABLY INVOLVING THE IMPAIRMENT OF CALCIUM INFLUX
}

\author{
Anna S. Belloni, Cinzia Tortorella, lucia Gottardo, Virgilio Meneghelli and \\ Gastone G. Nussdorfer', \\ Department of Anatomy, University of Padua, Via Gabelli 65, I-35121 Padua, Italy
}

\begin{abstract}
Adrenomedullin (ADM) and proadrenomedullin N-terminal 20 peptide (PAMP) are two hypotensive peptides, which are able to inhibit agonist-stimulated aldosterone secretion from adrenal zona glomerulosa. In this study we examined the effects of these two peptides on the aldosterone response of dispersed human adrenocortical cells to maximal effective concentrations of their main agonists. ADM $\left(10^{-7} \mathrm{M}\right)$ and PAMP $\left(10^{-8} \mathrm{M}\right)$ did not affect either basal or ACTH-stimulated aldosterone secretion, but they counteract ed the secretory response to both $10^{-9}$ $\mathrm{M}$ angiotensin-II (ANG-II) (partial inhibition) and $10 \mathrm{mM} \mathrm{K}^{+}$(complete inhibition). The $\mathrm{Ca}^{2+}$ ionophore A23187 $\left(10^{-5} \mathrm{M}\right)$ partially reversed the inhibitory effect of both peptides on aldosterone response to ANG-II, and abolished that on aldosterone response to $\mathrm{K}^{+}$. Collectively these findings provide indirect evidence that the mechanism underlying the aldosterone antisecretagogue action of ADM and PAMP may involve the impairment of the agonist-induced rise in the cytosolic $\mathrm{Ca}^{2+}$ concentration, and especially of $\mathrm{Ca}^{2+}$ influx.
\end{abstract}

Adrenomedullin (ADM) and proadrenomedullin $\mathrm{N}$-terminal 20 peptide (PAMP) are two hypotensive peptides, which are produced by the posttranslational processing of a 185 -amino acid pro hormone, named preproadrenomedullin (for review, see 10). Both peptides are expressed in the mammalian adrenal medulla, and the presence of specific receptors for ADM and PAMP has been demonstrated in the adrenal cortex, and especially in the zona glomerulosa (for review, see 9).

Like other regulatory peptides contained in adrenal medulla (for review, see 8). ADM and PAMP were found to modulate the secretory activity of the adrenal cortex. They specifically inhibit

\footnotetext{
${ }^{1}$ Correspondence to: G.G. Nussdorfer at the above address. Tel: $(+39)$ 49-827-2317; Fax: $(+39)$ 49-827-2319; E-mail: ggnanat@ipdunidx.unipd. it
}

angiotensin-II (ANG-II)-stimulated aldosterone production by dispersed rat $(1,5,6,11)$ and human zona glomerulosa cells $(2,3)$, without affecting either basal secretion or ACTH-stimulated one. There is also evidence that ADM hampers aldosterone response of rat zona glomerulosa cells to $\mathrm{K}^{+}$ (11), and that the mechanism underlying the aldosterone antisecretagogue action of ADM may involve the impairment of $\mathrm{Ca}^{2+}$ influx $(2,5,11)$.

PAMP was found to be significantly more effective than ADM in inhibiting ANG-II-elicited aldosterone secretion of rat and human adrenocortical cells $(1,3)$, but no data are at present available dealing with its possible mechanism of action. Therefore, it seemed worthwhile to study the effects of ADM and PAMP on the aldosterone response of human adrenocortical cells to their main agonists (ACTH, ANG-II and $\mathrm{K}^{+}$), and to ascertain whether the inhibitory effect of both peptides is 


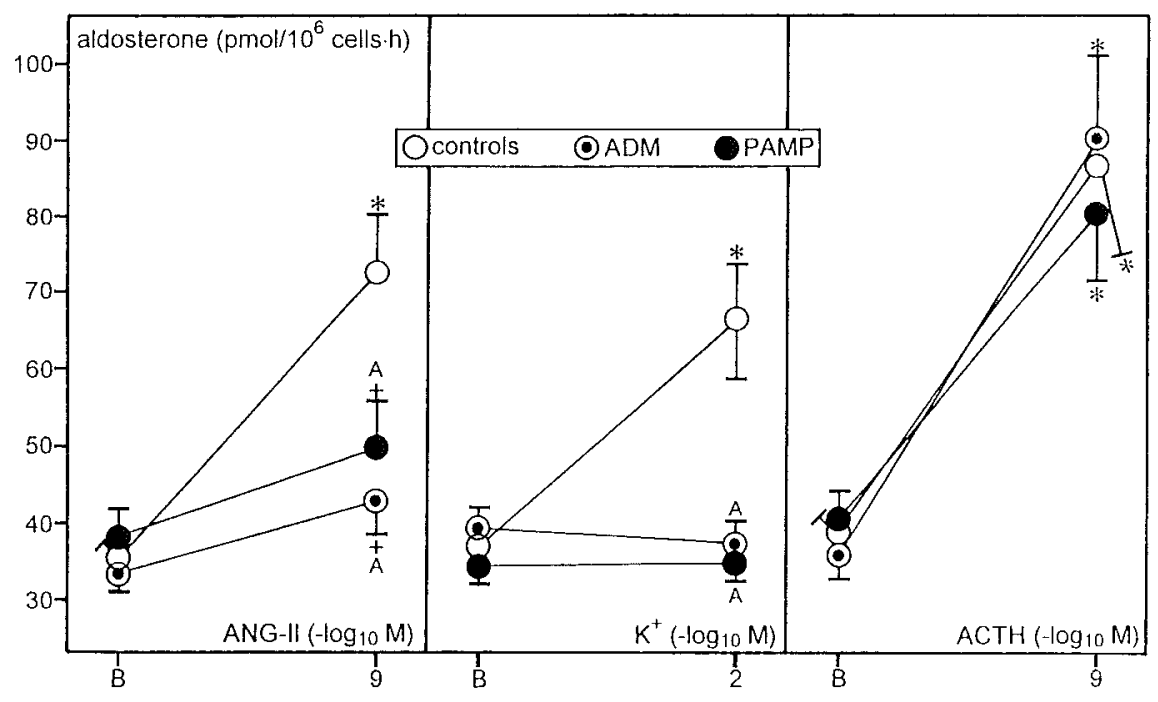

Fig. 1 Effects of ADM $\left(10^{-7} \mathrm{M}\right)$ and PAMP $\left(10^{-8} \mathrm{M}\right)$ on basal and agonist-stimulated aldosterone secretion of dispersed human adrenocortical cells. Data are means $\pm \operatorname{SEM}(n=3)$. ${ }^{+} P<0.05$ and $* P<0.01$ from the respective baseline values (B); ${ }^{A} P<0.01$ from the respective control groups.

counteracted by a $\mathrm{Ca}^{2+}$ ionophore.

\section{MATERIALS AND METHODS}

Human ADM(1-52), human PAMP, ACTH and ANG-II were purchased from Peninsula Labs (St. Helene, U.K.); the $\mathrm{Ca}^{2+}$ ionophore A23187, human serum albumin (HSA) and other laboratory reagents from Sigma (St. Louis, MO, U.S.A.); and Medium 199 from DIFCO (Detroit, MI, U.S.A.). RIA kit for aldosterone was purchased from IRESorin (Vercelli, Italy). Fragments of adrenal glands were obtained from six consenting adult patients $(40-50$ year-old) undergoing unilateral nephrectomy for kidney cancer. The study protocol followed the local Ethical Committee guidelines for human studies.

Adrenal tail fragments were employed to obtain dispersed cell preparations by collagenase digestion and mechanical disaggregation, as detailed previously (2). Dispersed cells obtained from each adrenal were placed in Medium 199 and Krebs-Ringer bicarbonate buffer with $0.2 \%$ glucose, containing $5 \mathrm{mg} / \mathrm{mL}$ HSA, and incubated $\left(3 \times 10^{4}\right.$ cells $/ \mathrm{mL}$, in replicates of three each) as follows: (i) $10^{-9} \mathrm{M}$ ANG-II, $10 \mathrm{mM} \mathrm{K}^{+}$or $10^{-9} \mathrm{M}$ $\mathrm{ACTH}$ in the presence or absence of $10^{-7} \mathrm{M}$ ADM $(1-52)$ or $10^{-8} \mathrm{M}$ human PAMP; and (ii) $10^{-9} \mathrm{M}$ ANG-II or $10 \mathrm{mM} \mathrm{K}^{+}$plus $10^{-7} \mathrm{M}$ ADM or $10^{-8}$ PAMP in the presence or absence of $10^{-5} \mathrm{M}$
A23187. The concentrations of ADM, PAMP and A23187 were those previously found to be the maximal effective ones in vitro $(2,3)$, and the same is true for the concentrations of ANG-II, $\mathrm{K}^{+}$and $\mathrm{ACTH}$ (4). The incubation was carried out for $90 \mathrm{~min}$ in a shaking bath at $37^{\circ} \mathrm{C}$ in an atmosphere of $95 \%$ air $-5 \% \mathrm{CO}_{2}$. Aldosterone was extracted from the incubation media and purified by high performance liquid chromatography (7), and its concentration measured by the ALDOCTK2 kit (sensitivity, $5 \mathrm{pg} / \mathrm{mL}$; intra- and inter-assay variation coefficients, $7.5 \%$ and $8.8 \%$, respectively).

Data obtained from each adrenal gland were averaged and expressed as mean $\pm S E M$ of three separate experiments. The statistical comparison of results was performed using ANOVA, followed by the Duncan's Multiple Range Test.

\section{RESULTS}

ADM and PAMP did not affect either basal or ACTH-stimulated aldosterone secretion of dispersed human adrenocortical cells, but they counteracted the stimulatory effect of both $10^{-9} \mathrm{M}$ ANG-II and $10 \mathrm{mM} \mathrm{K}^{+}$. Aldosterone response to ANG-II was only partially reversed (by about $60 \%$ ), while the response to $\mathrm{K}^{+}$was abolished. A23187 $\left(10^{-5} \mathrm{M}\right)$ partially blocked (by about $40-50 \%$ ) the inhibitory effect of both ADM and PAMP on aldosterone response to ANG-II, and annulled that 


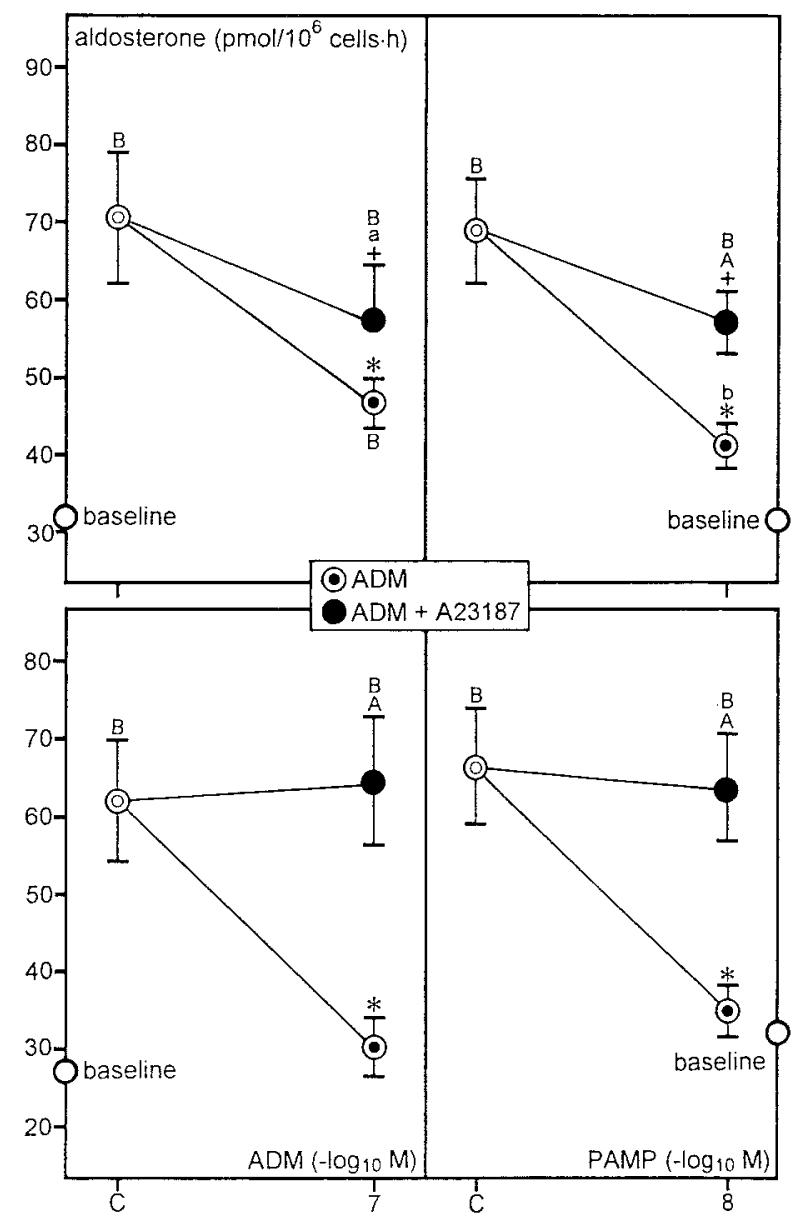

Fig. 2 Effect of $A 23187\left(10^{-5} \mathrm{M}\right)$ on the ADM- or PAMP-induced inhibition of aldosterone response of dispersed human adrenocortical cells to $10^{-9} \mathrm{M}$ ANG-II (upper panels) or $10 \mathrm{mM} \mathrm{K}^{+}$(lower panels). Data are means \pm SEM $(n=3) .{ }^{+} P<0.05$ and $* P<0.01$ from the respective control groups $(C$, secretory response to agonists in the absence of ADM or PAMP); $P<0.05$ and $A P<0.01$ from ADM or PAMP only exposed groups; ${ }^{\mathrm{b}} P<0.05$ and ${ }^{\mathrm{B}} \mathrm{P}<0.01$ from the respective baseline values.

on aldosterone response to $\mathrm{K}^{+}$(Fig. 2).

\section{DISCUSSION}

The present results confirm that ADM and PAMP specifically inhibit the aldosterone secretagogue effect of the agonists, whose signaling mechanism involves the rise in cytosolic $\mathrm{Ca}^{2+}$ concentration $\left(\left[\mathrm{Ca}^{2+}\right]_{\mathrm{i}}\right)$, which in turn activates protein kinase - C (PKC) cascade (for review, see 9).

It is current knowledge that the mechanisms whereby $\mathrm{ANG}-\mathrm{II}$ and $\mathrm{K}^{+}$elicit the increase in
$\left[\mathrm{Ca}^{2+}\right]_{\mathrm{i}}$ are quite different (for review, see 4). ANG-II, by interacting with specific AT1 receptors, activates phospholipase $\mathrm{C}$ and consequently raises the production of $\mathrm{IP}_{3}$, which enhances $\mathrm{Ca}^{2+}$ release from intracellular stores, and of diacylglycerol, which directly activates PKC. Moreover, ANG-II increases $\mathrm{Ca}^{2+}$ influx. Conversely, the mechanism of action of $\mathrm{K}^{+}$exclusively involves the opening of voltage-gated $\mathrm{Ca}^{2+}$ channels. Hence, the demonstration that ADM and PAMP abolish the aldosterone response to $\mathrm{K}^{+}$, but only partially reversed that to ANG-II, strongly suggests that both proadrenomedullin-derived peptides exert their antimineralocorticoid action mainly by blocking $\mathrm{Ca}^{2+}$ influx.

This contention is supported by the finding that a potent ionophore, at a concentration which has been previously found to induced a sizable increase in aldosterone secretion of human adrenocortical cells (2), annuls the inhibitory effect of ADM and PAMP on aldosterone response to $\mathrm{K}^{+}$, but only partially counteracts that on the response to ANG-II, in which PKC activation is not exclusively mediated by the rise in $\left[\mathrm{Ca}^{2+}\right]_{\mathrm{i}}$.

In conclusion, our study provides indirect evidence that ADM and PAMP are able to impair $\mathrm{Ca}^{2+}$ influx in human adrenocortical cells, and investigations are under way to ascertain which type of $\mathrm{Ca}^{2+}$ channels ( $\mathrm{T}$ - or L-type) is blocked by these regulatory peptides. However, the possibility cannot be ruled out that both proadrenomedullin-derived peptide may also somehow interfere with the $\mathrm{IP}_{3}$-mediated $\mathrm{Ca}^{2+}$ release from intracellular stores.

Received 9 February 1998; and accepted 6 March 1998

\section{REFERENCES}

1. Andreis P.G., Mazzocchi G., Rebuffat P. and Nussdorfer G.G. (1997) Effects of adrenomedullin and proadrenomedullin N-terminal 20 peptide on rat zona glomerulosa cells. Life Sci. 60, 1693-1967

2. Andreis P.G., Neri G., Prayer-galetti T., Rossi G.P., Gottardo G., Malendowicz L.K. and Nussdorfer G.G. (1997) Effect of adrenomedullin on the human adrenal glands: an in vitro study. J. Clin. Endocrinol. Metab. 82, $1167-1170$

3. Andreis P.G., Tortorella C., Mazzocchi G. and NussdorFER G.G. (1998) Proadrenomedullin N-terminal 20 peptide inhibits aldosterone secretion of human adrenocortical and Conn's adenoma cells: comparison with adrenomedullin effect. J. Clin. Endocrinol. Metab. 83, 253-257

4. Ganguly A and Davis J.S. (1994) Role of calcium and other mediators in aldosterone secretion from the adrenal 
glomerulosa cells. Pharmacol. Rev. 46, 417-447

5. Mazzocchi G., Rebuffat P., Gottardo G. and Nussdorfer G.G. (1996) Adrenomedullin and calcitonin gene-related peptide inhibit aldosterone secretion in rats, acting via a common receptor. Life Sci. 58, 839-844

6. Neri G., Andreis P.G., Meneghelli V. and Nussdorfer G. G. (1997) Effects of adrenomedullin and proadrenomedullin $\mathrm{N}$-terminal 20 peptide on steroid production in dispersed rat adrenal zona glomerulosa cells. Biomedical Res. 18, 365-368

7. Neri G., Andreis P.G., Prayer-Galetti T., Rossi G.P., Malendowicz L.K. and Nussdorfer G.G. (1996) Pituitary adenylate cyclase-activating peptide (PACAP) enhances aldosterone secretion of human adrenal gland: evidence for an indirect mechanism probably involving the local release of catecholamines. J. Clin. Endocrinol. Metab. 81, $169-173$

8. Nussdorfer G.G. (1996) Paracrine control of adrenal cortical function by medullary chromaffin cells. Pharmacol. Rev. 48, 495-530

9. Nussdorfer G.G., Rossı G.P. and Mazzocchi G. (1997) Role of adrenomedullin and related peptides in the regulation of the hypothalamo-pituitary-adrenal axis. Peptides 18, 1079-1089

10. Richards A.M., Nicholl.s M.G. and Lainchbury J.G. (1996) Adrenomedullin. Clin. Sci. 91, 3-16

11. Yamaguchi T., Baba K., Dor Y. and Yano K. (1995) Effect of adrenomedullin on aldosterone secretion by dispersed rat adrenal zona glomerulosa cells. Life Sci. 56, $379-387$ 